\title{
An Appraisal Look into Shielded Online Education in Covid Era: Resilience Revisited
}

\author{
Mojtaba Teimourtash ${ }^{1}$, Morteza Teimourtash ${ }^{2}$ \\ ${ }^{1}$ Science and Research Branch, Islamic Azad University \\ ${ }^{2}$ Shahr-e-Qods Branch, Islamic Azad University
}

\begin{abstract}
Correspondence concerning this article should be addressed to Morteza Teimourtash, Department of English, Faculty of Humanities, Shahr-e-Oods Branch, Islamic Azad University, Tehran, Iran.
\end{abstract} E-mail: teimourtash2000@gmail.com

\begin{abstract}
Education has been regarded as the backbone of human advancement in all areas of activities as the ultimate goal of education is to develop better citizens. Online Education has been known as the alternate approach to learning. The outbreak of Covid-19 virus has infected all nations in the world and debilitated all areas of human activities, hence, education was not an exception. The dominancy of online education in Iran experienced a breakthrough during Covid pandemic and like other activities, it witnessed a fragile stance, and, in a nutshell, reality was far from ideality. The present study aimed at depicting the adversities exerted during the implementation of Online Education in Covid pandemic era and the term Shielded Online Education could vividly justify online programs in higher education. Learners showed an astonishing accomplishment attending shielded fashion of online education in Iran in such a way that a new definition to the notion of resilience could be introduced. A resilience questionnaire before and after an online course in the second semester of the academic year 2020-2021 was conducted with 60 junior undergraduate EFL learners majoring at Translation in Islamic Azad University Tehran. The Resilience Questionnaire was collected from control group and the experimental one. The data obtained went through quantitative data analysis confirmed that shielded online courses outperformed significantly in enhancing the learners' resiliency in Covid era and what was gained was far beyond what was expected. The education stakeholders, policymakers, teachers and syllabus designers could benefit from the findings of the present study which in turn could shed light on the ins-and-outs of the maneuverability aspects of better enactments of online courses through online education.
\end{abstract}

Keywords: shielded online education, Covid pandemic, resilience

\section{Introduction}

The societies in the world experienced a devastating period in 2020 due to Covid-19 pandemic hence the field of education was not an exception. It is taken for granted that learning agenda is a dynamic process and it never stops and could never be stopped. Covid virus has been a fatal issue which hindered the education realm to a great extent, but the dynamic nature of the education agenda could not tolerate any halt in between. The advent of distance learning with the help of computer sciences has long been the focus of attention for scholars and specialists in education. The emergence of Covid pandemic made stakeholders and policy makers in education field focus on online learning as the best and last resort to the popped-up pandemic. As scholars believe that the notion of online education has been on the fringe for so many years, hence, Covid outbreak made it the mainstream trend in education (Chakraborty et al., 2020). Much like other countries, Iran followed the same prescription, and the internet and telecommunication infrastructure were employed to run and survive the educational system and to turn the Covid challenge and threat into a brand new opportunity in order to dodge the situation imposed in the most proper fashion. Of course, the confusion and the anxiety prevailed in Iran both medically and educationally (Fardin, 2020) along with the great concern to control the pandemic due to the geographical extent of Iran (Abdi, 2020) and the wide distances among provinces had exacerbated the situation. There have been three semesters up to now that online education is prevalent in Iran academic and educational zone. The present study was conducted in the second semester of the academic year 2020-2021. 
The notion of adversity and adversity quotient as a real ingredient of individuals in $21^{\text {st }}$ century was first proposed by Stoltz (1997). To Stoltz, the world is replete with bunch of adversities and different individuals may respond differently once encountering an adversity. The point is that adversities could not be predicted or forecasted in advance and in any form. The adversity quotient (AQ) was also his exclusive proposal and drew the attention of many scholars and practitioners. According to Stoltz, $\mathrm{AQ}$ is the power of facing adversities and difficulties and it encompasses three categories of climbers, campers and quitters. The adversities such as the outbreak of Covid-19 might have had great influence on the trends of lives by many people around the world and one could barely find those equipped with $\mathrm{AQ}$ who turn obstacles into opportunities. Educational systems replaced traditional methods for online education (Liguori and Winkler, 2020). The emergence of online education as an inevitable must in academic and educational realm was once touched by learners and even some instructors as quitters. The prolonged process of exploring the Covid vaccine made most educators welcome online education as the Hopson's Choice and follow the guidelines. The second academic semester which was also announced to be held in online fashion somehow convinced most educators as online education could be the best and last resort to the Covid pandemic in academic realm. So, the population of the quitters hopefully shrunk and there were two categories of climbers and campers left. Unbelievably, the population of the climbers were many times as much as the campers and the researchers in the present study found the reason behind such contamination of academic population towards the resilience and accepting climber position rooted in the advantages of utilizing shielded Covid online education in academic realm and in the present paper, the researchers would justify such findings using data collection and statistical analysis as follows.

\section{Literature Review}

The importance of education is so dynamic and high by nature that it should not be delayed due to any deficiencies such as the pandemic infectious diseases as SARS or Covid-19. The distance mode of learning is a justifiable substitute in order to make up for the notion in emergencies. The significance of distance learning and online education provide room for the geographically isolation of the classroom elements and the instructors may conduct classes far from the presence of learners and the construct of distance may affect learners not to be able to establish proper connection to the agenda (Suen \& Parkes, 1996, cited in Lee \& Chan, 2007).Such deprivation from social interactions and socio-cultural factors might in turn hinder the process of learning to take place properly (Lee \& Chan, 2007). The routine classroom settings afford active interactions between teachers and learners in an ongoing fashion, hence in distance and online classrooms such interactions and involvements of the learners in the learning process are absent. It is worth mentioning that the active interaction mentioned above was of all kinds. Even tea-time or leisure times are significant in the face-to-face learning environments. Cracking jokes or establishing rapport work. Sense of humor in the academic world might signals creativity and supportive course of actions. Of course, online fashion of education through which learners lack active presence in real classrooms might be regarded as humor hindrances and barriers (HeidariShahreza, 2020). Of course, it is educationally taken for granted that online learning would be different from emergency remote teaching, while online education would be more sustainable and is preferred once the instructional activities render more hybrid, provided that the challenges imposed during Covid pandemic be well explored and transformed into opportunities (Adedoyin \& Soykan, 2020). Chen and Martin (2007) believe that different learners may interpret behavioral reflection such as humor differently and might display different attitude. The attitudes and feedback of learners to the contexts might become out of the control of the online teachers, but what signify are the contextual factors which make humor stances understandable (Mireault \& Reddy, 2016). Of course, the teachers are equipped with the proper knowledge and experience to manage the online classes and the deformation or the reconstruction of the learning environments might least affect their management and control of the scene, i.e., the teachers get involved in a new fashion of practice as online fashion. It is as if in online classes, the education system is not altered fundamentally, but re-wired and reengineered to adapt to new academic style which is immersed in technology and smart devices.

As the shortcomings, learners in distant and online learning are deprived of active interactions with peers and other classmates which might act as dampers and hindrances to learners' motivation and enthusiasm (Hutton, 1998), and that is the reason why learners in online classes demand a higher degree of initiatives and mental or psychological resilience above and beyond those required in routine traditional classes (Reeves, 2000; Essadek \& Rabeyron, 2020; Savage et al., 2020). Henceforth, Computer Assisted Language Learning (CALL) might be the 
core momentum in distance or online education as it has got the remarkable vantage points as needed. The prevalence of information and the feasibility of having access to myriad of information through CALL courseware (Wang, Chen, \& Zhang. 2021) embedded into regular routine educational environments and settings in order to maximize the uptakes of different learners with different tastes at a real-time fashion would empower learners to challenge online classes and even teachers. Of course, there exists an underlying gentle shift of power in establishing online courses as Shneiderman (1993) stresses that new communication technologies provide new challenges in educational environments as learners are empowered in remarkable ways. Like any other mutual interactions, new communication technologies offer the power shift in human interactions as Rumble (1995, cited in Sumner, 2000, p.278) asserts technologies as the excuse in the "distribution of power" in any fixed long-practiced interactions by individuals. This issue could be depicted concerning the idea that knowledge is power and through being immersed in the oceans of information, the balance of power distribution is agitated and in most cases such as online education, the power balance equation would experience a new equilibrium. It is as if the authoritative role of teachers in online classes would be lost or shrunk as a result of the power loss they experience.

Along the advantages of the online courses, distance and online education suffer largely from the high rate of drop-outs (Kember, 2003). Peters (1992) asserts that the definition for drop-outs encompasses those who also attend online classes but "does not sit examination" (p.235). There might exist many problems resulting in online education drop-outs, but more significantly the radical reason behind such phenomenon might be rooted greatly in the physical isolation and dispersed attendance experienced by the online educators (Lee \& Chan, 2007). Considering academic online education during Covid pandemic in Iran, many instructors witnessed and complained such lack of having a sense of belonging to university and academic atmosphere from the learners' sides. Scholars believe that such perception of not belonging to scholarly community (Wang, Bergin, \& Bergin. 2014) would result in vanishing the motivation and enthusiasms of learners in perusing their academic progress. Such dissatisfaction or confusion from the learners' side might be rooted in the mismatch in online teaching by professors experiencing a great shift of transition from accustomed knowledge dissemination into online fashion of teaching (Maggio, Daley, Pratt, and Torre. 2018.; Chakraborty, Mittal, Gupta, Yadav, and Arora, 2020).

The social context in online education seems to be ignored as policy makers put more emphasis on the dominancy of online education for the sake of surviving the situation and for the academic world to dodge the Covid pandemic in no time. The truth is that reality is far from ideality. What happens in practice has a long way to be documented and turned into body of knowledge for further study. The environmental effect of the classroom settings is part of the social factors affecting learning process. In academic settings Learners wear formal cloths and attend formal educational settings in routine classes. The academic atmosphere learners inhibit and enjoy on a span of time during academic semester could be regarded as part of learners' social identity (Pierce, 1996), the notion ignored during Covid pandemic online education. Learners put on their casual cloths and attend online classes in the most informal manners and positions as possible which may in turn affect the social identity of their presence in online education. Such notion might be considered as the lack of feedback from peers, lack of motivations, and negative emotions (Patricia, 2020). Having the slightest feedback from peers and experiencing lack of motivation or even negative emotions that come from the solitude fashion of learning may hinder the process of learning in online education from actively taking place what was prescribed and expected.

There has been a plethora of research in education realm which delve into the great shift of attention from teacher-centered to learner-centered education, spotlighting the notion of autonomy. The studies conducted in Asian countries in this regard have been numerous such as those in Japan (Mitchell, 2017), Iran (Papi, 2010), Pakistan (Islam et al. 2013), and China (Liu and Huang, 2011) which all confirmed the notion of autonomy to play a pivotal role in recent years. The notion of autonomy was also followed in distance and online education (Tullis \& Camey, 2007). Henceforth, the emergence of Covid pandemic has revisited the notion of autonomy with a new definition to what Holec (1981) proposed autonomy as, "the ability to take charge of one's learning" (cited in Thanasoulas, 2000). The Covid pandemic draw a new sub-branch of autonomy in online Covid pandemic education where the blind learners should become capable of taking charge of their own learning process to be taken place in time and be followed in an idiosyncratic pattern judged by the learners to be suitable to certain knowledge dissemination taking place in real-time fashion in online classes. The educational settings in Covid pandemic seem to be distorted to the extent that rarely the established formula deem to work 
and render applicable. Ribeiro (2020) highlighted that this digital transformation of instructional delivery in Covid era came with new challenges and attitudinal medications and the truth is that education system is highly susceptible to external dangers (Bozkurt \& Sharma, 2020). There are no vivid clear-cut clue works for all the Covid online educational settings and there seems to exist a sense of uncertainty theme prevalent in the body of the online settings.

What exacerbates the insecurities (Kinzie, 2010) experienced by online and distance educators lies in the lack of prompt feedback from the professors, the lecturers and the peers in comparison to the regular face-to-face classes because some of the problems prevail in routine classes are simply rectified by the clues provided by peers and classmates, and some are left untouched to be rectified by the instructors. Professors are recommended to provide some flexibility to students attending online courses (Mahmood, 2020). The implication of various technology-based applications has smoothen the process but has not yet compensated for the absence of peer feedback as scholars believe that: "there was still no affordable way for them to participate in synchronous interactions which were flexible as to time,fluency and the numberand composition of participating groups.”(Kötter, Shield, \& Rodine, 1999 cited in Hauck \& Haezewindt, 1999, p. 47)

Lack of flexibility (David, 2011) could be regarded as one of the underpinning hindrances to online education. To be honest, most teachers and instructors might suffer from the technological infrastructures needed to establish a proper ground to hold online classes in Covid pandemic satisfactorily. In a study conducted just before the Covid-19 pandemic, Lembani, Gunter, Breines, and Dalu (2020) found that a digital divide between urban and rural areas exists, and students in rural areas often do not have adequate access to digital data bases and information or communication technology. Grishchenko (2020) also pinpointed that sustained access to digital technologies is an important prerequisite for online education and economically disadvantaged individuals like those living in rural areas often suffer from their limited or lack of access to digital technologies. Considering the scenario and incapability of learners to adapt themselves to the online education prerequisites, some instructors might follow certain policies just followed in routine classes and the moment learners could not respond or not have the secure connection to respond to the proposed item by the instructor might lead to losing some point and receiving some negative marks from the instructors. Such behaviors and hasty feedbacks might lead online learners to lose their enthusiasm and in turn de-motivate them to a large extent. So, flexibility should be applied and dominated from both sides of teachers and learners in order to establish a mutual understanding of the attended situations of online education in Covid pandemic. Of course, if there exists any prompt visual feedback, the scenario would be different and the teachers would show proper understanding of the occasion in due time.

\section{Covid Online versus NON-Covid Online Teaching \& Learning Circumstances}

Online fashion of holding classes is not the issue raised merely due to the Covid pandemic situation, but the emergence of the online classes and courses might go back to the introduction of computer software into educational realm. Hence, the construct of online classrooms has experienced a great shift due to Covid pandemic. The Covid-19 pandemic provided both teachers and learners with the opportunity to introduce digital learning (Dhawan, 2020), the opportunity to be motivated to enhance digital competency and to remain relevant in modernity (Omotayo and Haliru 2020). Just like any other breakthrough in the world such as World War II, two courses of actions regarding online classes could be considered as Online courses before Covid and Online courses during Covid pandemic, to put it into a proper fashion as: Ante-Covid and On-Covid Online courses circumstances. The advent of online courses was inaugurated once the distances between the specialists' locations or institutes and foundations and the people who were in need of obtaining certain knowledge were so far. There was no financial briefing or economic justification for asking the specialists to take the burden and travel so long and, for instance, spend two days for just conducting a 4-hour course. What prevails in the afore-mentioned scenario bests depicts the shift of online courses before and during Covid pandemic. In AnteCovid circumstances, people enrolled in a course get together in a learning environment by an institute or a learning center, then they attend an online course together in the presence of an absent instructor whose presence was available through the monitor screen and the internet-based communication. In Ante-Covid online courses, classes were conducted regularly in the axis of two notions of TIME and PLACE, i.e., the two notions of time and place were followed and observed. Only the presence of the instructors was online in the Ante-Covid online classes. The point is that the learning environment was attended, observed and established. The learners could enjoy the sense of a real classroom with the same discipline as the regular one. The question- 
and-answer atmosphere was also established through online classes and the real-time classroom standards was compatible with those of the ordinary classes and courses. The notion of presence in the place of education as one of the significant factors in learning process was observed and available then.

In On-Covid pandemic online courses, the notion of PLACE is ignored and left untouched. Learners would experience a learning process even in their bedrooms or workplaces as the classrooms. What exacerbates the situation is that learners would have the slightest idea what could be the trend of the course just because the immediate or ongoing feedback from peers is omitted or vanished in On-Covid online classrooms (Patricia, 2020). That is not the case for the teachers as they are placed in virtual classrooms and the instructors and teachers observe the classroom settings because they could slightly sense such a class by looking at screens before them and noting the enrolments and the list of the attendees in their classes, but what is happening at the other side of the online lines? It is shielded for both sides. Do learners really enjoy and usurp the presence and attendance of their peers? Do they have or could they enjoy any panel discussion? The students might have had acceptable performance for not losing the academic year; hence the radical issues need more investigations (Hasan and Bao, 2020). Of course, in some courses and in rare cases, panel discussions could be available, but such availability is established at the expense of loosing time, energy, the internet connections and a lot more. Here it means the respected feasibility is highly required in order to have online panel discussions or follow any peer correction agendas. In reality, the probability estimate of such utopia is near zero. The dark side of the issue is that no one raise or care or at least spotlight the notion of PLACE as the missing point in boosting the running online education in On-Covid pandemic era for the stake holders or specialists and policy makers in order to pinpoint the issues in their minds and conduct studies in order to eradicate or smoothen the learning process in such a way that learners get involved in the sense of attending realistic virtual online classrooms just the same as the real classrooms with certain established rules and regulations. It is as if "six of one" and "half a dozen" both imply one single concept of "six"; hence the cumulative uptake due to the impression of enjoying adjacency by individuals is dodged once individuals attend online courses in solidarity.

\section{Weak Version vs. Strong Version Shielded Online Education}

Shielded online education could be considered in two important versions: Weak Version and Strong Version. Weak version of shielded online classes refers to the condition of the figurative protective shield in front of the learners' face and s/he experiences a sense of being guarded against virus in the first place as everybody else, but more importantly s/he senses the position of being guarded against any interference by the teachers or instructors on the other side of the line in the online classrooms. The weak version is best experienced by learners and most teachers may neglect such sense and consider it as a routine position of the settings in the online classrooms just because there are not any other kinds of interactions present in such online settings. Of course, learners might not wear protective shields while attending the online classes and the bright glass of their electronic devices such as laptops, smart phones, computer devices or tablets would act as the shield between the instructors and the learners as the attendees of the online classrooms. Such absence of direct eye contact could be regarded as the proper shield on the side of the learners to compensate for any shortcomings from their own sides. Such notion might be best justified by the shield to cover the online learners' anxiety and distress they suffer while attending online classes (Essadek \& Rabeyron, 2020; Islam et al., 2020).

The strong version of shielded online education is the figurative protective shield being worn by the instructors. Of course no one of the professors wear a protective shield while teaching online classes but here again the shield or the display screen and camera lens could be regarded as the figurative shield which impedes the prompt contamination or formation of knowledge bridge to take place and the instructors would not have a prompt online feedback from the learners' side to check and ascertain promptly whether they follow the instructions provided by the instructors regarding the subject matters for the learners in online classes. Of course, instructors and teachers may use innovative tools and techniques for the students in order to keep the teaching-learning process on the right track (Arora, Chakraborty, Bhatia, \& Mittal, 2020). The online classroom settings are so much alike talking to a bunch of learners each seated in a far place physically and such attentioncollecting act of the instructors may fade due to such dispersed imagined positions of the learners' in the online classrooms. Such issue exacerbates once the instructors activate the learners' microphones and the ambient noise ascertain the presence of each learner in different location. Locations such as the workplaces, behind the rolls, in the malls and markets, at homes, outdoors, etc., all of which confirm in the minds of the instructors the concern that the important notion of learning environment is not observed by online learners. 


\section{Shielded Covid Online Education and Adversity Notion in Practice}

The notion of adversity and adversity quotient was proposed by Stoltz (1997) and it embraced educational settings as there might exist opportunities within and inside any adversity experienced by learners. Individuals facing adversities in life such as adversities in academic life might put on different position as climbers, campers and quitters. The significant characteristic of adversities is the unpredictability in the nature of adversities. Covid pandemic and the online education could be best regarded as the twenty-first century biggest educational adversity. As proposed in the present paper that the idea of shielded Covid online education has got a new definition with new dimensions and pitfalls. Of course, the obstacles and opportunities in Covid online education are not fixed to be predictable for each learner. The related literature in Covid educational realm is high yet demanding and unorganized to the extent that various categorization could be applied to the issue at hand. What signifies here is that the rule of thumb is applicable both in space and on Earth. That is to say, the rules and regulations are fixed and applicable even to Covid pandemic era, hence the input data might seem bewildering and vague due to lack of literature in this regard. One of the demanding issues in this vein is the learners with special educational needs having learning difficulties, such as hearing impairment, visual impairment and mobility disabilities, which in turn require additional training with careful support and precise supervision. The capability to cater such educational needs could be regarded as a real educational adversity for parents and caregivers at home or regarded as a real threat and hindering issue in the learning process of such group of learners (Pokhrel and Chhetri, 2021).

\section{Adversity and Resilience in Mutual Bilateral Interactions}

Stoltz $(1997,2000)$ asserts that adversities are essential unpredicted part of individuals' lives and declares that without adversities, there is no story to tell. What signifies in the notion of adversities proposed by Stoltz is that the maneuverability of individuals in facing the adversities is of great importance. Adversity and resilience are the two sides of a single coin. In better words, resilience is the positive adaptation to adversities. The golden phrase in Stoltz (1997) definition of adversities is the title of his work as adversity and adversity quotient is the key in turning obstacles and challenges into opportunities. That is the philosophy behind any change in the world that individuals should be ready at any time and any place to welcome any adversities and view them as new opportunities which were formerly regarded and deemed as obstacles. Such stance of view is not a brand new one, but the wording is reengineered and rewired to match and render applicable to new Covid era's circumstances (Bao, 2020). Regarding distance and online education, Morgan and O'Reilly (1999) urge learners to view such model in artificial realistic world as "opportunities" model, rather than a "deficit" model (p.23).

In Covid pandemic, the world faced an unpredicted stop-point to any activities in the run and encountered an adverse halt abruptly. The dynamic academic and educational world was also affected and led to a near-static deposition. As the fatal Covid virus was not controllable in a short timespan due to biomedical significance, the policy makers in educational realm decided unanimously to resort to online programs in order to keep the educational zone in track. Like any other systems in strict-measure-periods, educational and academic realm also faced some adversities in implementing the new trend of educational practice worldwide. Of course, "normalizing the new normal" (Carroll and Conboy 2020) has been the great concern of educational systems at a global scale. In Asian countries such as Iran the trouble was doubled just because the great body of higher education demanded a giant capacity to hold five million classes online in a single session of a day. Of course, in normalizing the new normal globally, universities in Iran could successfully meet the required standards and conquered the adversities imposed by Covid pandemic in a gentle fashion.

The present paper aimed at touching the resilience level of the convenient sample of 60 undergraduates studying at Islamic Azad University in Tehran. The 60 undergraduates experiencing the second semester of the academic year 2020-2021 in Covid pandemic era were asked to answer the Resilience Questionnaire before and after their course content in the semester, i.e., the first and the last session of the afore-mentioned semester. The online courses opened a new horizon before undergraduates as, by the help of the teachers, learners could turn obstacles into learning opportunities. The shielded online courses provided learners with brand new opportunities which were rarely found in traditional face-to-face practice. The notion of face-to-face anxiety, readiness, stress, losing face and prompt feedback could be some of them. The researchers of the present study encountered astonishing findings that the shielded online courses outperformed the traditional face-to-face 
courses and decided to share these findings through the present paper. To conduct the study, the following research question was proposed.

\section{Research Question}

Does online fashion of education in Covid pandemic era have any statistically significant impact on enhancing the resiliency of EFL learners in confronting the embedded adversities?

\section{Methodology}

\section{Participants}

The subjects participating in the present study were selected through convenient sampling and the they were 60 junior undergraduates studying at Islamic Azad University in Tehran. The age range was between 19 and 33 and they all had experienced routine academic sessions in university before Covid pandemic. The Oxford Placement Test (Appendix A) was administered for observing language proficiency and homogeneity of the 60

upper intermediate level subjects of the study. The study was conducted in the second semester of the academic year 2020-2021 and the participants were all majoring at English Translation Discipline. As the convenient sampling was utilized, and the participants were all at upper-intermediate level of language proficiency, randomization had no place in the present study. The participants were informed about the aims, scope and objectives of the present research and the confidentiality of their personal information were assured. The 60 participants were randomly divided into two groups: an experimental and a control group, and there were 30 students in the experimental group and 30 students in the control group. The language of the questionnaire was English and as the language proficiency level was intermediate, the participant had no difficulty to take the questionnaire and there was no need to translate the test items.

\section{Design}

The quantitative design was applied to the present study, and in order to fulfill the aims of the present study, non-probability sampling or continent sampling was utilized and the readily available 60 upper intermediate EFL learners in the junior level majoring in English translation discipline were asked to take part in the study. The researchers employed the descriptive research design to determine the inter-relationship of the dependent and independent variables. The present study which considered the educational challenges imposed to teaching and learning agenda due to the online classes conducted in Covid-19 pandemic era had the dependent variable as the shielded fashion of online education in Covid era, meanwhile, the independent variable in the present study was the resiliency level of EFL junior undergraduates tested through resilience scale questionnaire. Given the great resistance endured by both teachers and learners, some good vantage points were noticed, examined, and highlighted by the researchers of the present study which were rooted in the underlying question aimed at delving into the impact of shielded Covid pandemic online classes on enhancing and improving the resiliency level of EFL learners in Iran.

\section{Instruments}

\section{Oxford Placement Test (OPT)}

OPT was used in the first session of the research time span in order to ascertain homogenous groups of participants for the study. In order to check the reliability of the Oxford Placement Test, it was piloted with thirty EFL learners of the same age and proficiency level attending Islamic Azad University majoring at English translation discipline. The reliability of the OPT through Cronbach's alpha analysis was performed, the result $(\mathrm{r}=0.82)$ indicated that the test was reliable.

\section{Resilience Scale Questionnaire (RSO)}

The instrument utilized in the present study was the Resilience Questionnaire (Appendix B). The Resilience Questionnaire or Resilience Scale (RS) was designed and developed by Wagnild and Young (1993) and is known as one of the best tools for measuring resilience which is considered as the amalgamation of positive personal 
attributes of individuals' adaptation in facing adversities. The resilience questionnaire items were developed through data collection process obtained from several systematic interviews with 24 women who displayed healthy socio-emotional functioning followed by a great loss. Wagnild and Young (1993) identified and categorized five personal attributes leading to resilience: equanimity (encompassing individuals' life background and experiences), perseverance (confronting and resisting odds), self-reliance (the individuals' knowledge of self-strength, weak points and limitations), meaningfulness (individuals' targets and aims in life) and existential aloneness (the uniqueness and individualist shareable approach to the experiences of individuals). The Resilience Questionnaire or Scale is a 25-item questionnaire with a seven-point Likert scale with higher scores showing stronger resilience. No reversed score items were allowed and in the psychometric measurement the mean score was 147.91. Scores above 146 should be considered high (Wagnild \& Young 1993). The RS has been translated and converted in loyalty to the contents into at least 36 languages (Wagnild 2013). Although the content validity was subjective, Wagnild and Young (1993) hypothesized the obtained data would fit a five-factor model. According to Wagnild (2013) alpha coefficients ranges within 0.85 and 0.94.In Wagnild and Young (1993) the coefficient alpha was 0.91.

\section{Verification of Scale}

Concerning the reliability index of the instruments utilized in the present study, the following table (Table-1) was systematically provided to verify the reliability of the instruments of the present study. Research authorities such as Kline (2000) believes that the criteria concerning internal consistency of .90 should be regarded as an excellent fit, from .90 to .70 as a good fit, and between .70 and .60 should be regarded as an acceptable fit.

\section{Table 1}

Verification of Scale

\begin{tabular}{lcc}
\hline & Oxford Placement Test (OPT) & Resilience Questionnaire \\
\hline Alpha & .82 & .92 \\
Mean & 15.53 & 23.21 \\
SD & 6.38 & 6.25 \\
\# of items & 100 & 25 \\
\hline
\end{tabular}

Needless to highlight that the calculated values for the Resilience Questionnaire as the main instrument utilized in the present study exceeded the threshold to be considered as good fit. This means that the resilience scale as the sole instrument utilized in the pre-test and post-test phases of the present study was reliable. Validity of the Instruments was also confirmed prior to the implementation of the treatment and was brought into attention in instrument section. The instrument held validation by content and face-to-face validity methods. For validity, the instruments were also checked for any misconception by the experts and scholars in the field.

\section{Research Procedure}

The procedure for obtaining the required data of the study in order to delve into the research question concerning the impact of shielded online education in Covid pandemic era on improving the resiliency level of EFL learners in Iran followed a very gentle procedure as the convenient sampling design was applied and the readily 60 EFL learners majoring in English discipline were asked to take the RS questionnaire in the first session of the second semester in academic year 2020-2021 and the data were collected as the pre-test data. The participants were junior undergraduates who held sufficient language proficiency level to take part in the study and there was no need to provide them with the translated version of the resilience scale questionnaire. 60 participants in the present study were also asked to take the same resilience questionnaire at the final session of the class at the end of the semester and it was considered as the post-test phase of the study. The classes were held once a week for 90 minutes for 16 sessions. The control group enjoyed routine face-to-face conventional class with the same teacher and the same course book as the experimental group, while the experimental group attended online education fashion of teaching and no presence was allowed to the group members. 


\section{Data Analysis}

To answer the research question contending whether online education in Covid pandemic era has statistically significant impact on enhancing the resiliency level of EFL learners in Iran, quantitative data were gathered through the instrument of questionnaire. The data collected through quantitative observations of the $60 \mathrm{EFL}$ learners in the target groups were analyzed using the SPSS21 software through descriptive statistics and paired-samples T-Test statistical procedure was used, but as using T-Test requires checking the normality assumptions, at first, these assumptions were checked (Bachman, 2005) to indicate a numeric summary of occurrence of the observed behaviors and the obtained scores in target group, also to examine whether they differed significantly.

\section{Results}

Normality Assumption - The normality of the data was measured by calculating the ratios of Skewness and Kurtosis on their respective standard errors. Based on the results display in Table 2, it could be concluded that the data collected in pretest and posttest phases of administering resilience questionnaire scale enjoyed a normal distribution.The ratios were all lower than the absolute value of 1.96.

Table 2

Testing Normality Assumption

\begin{tabular}{llllc}
\hline \multirow{2}{*}{ Group } & & \multirow{N}{*}{} & Skewness & Kurtosis \\
\cline { 4 - 5 } & & & Ratio & Ratio \\
\hline \multirow{4}{*}{ Experimental Control } & Pre-RSQ & 30 & -0.50 & -1.27 \\
& Post-RSQ & 30 & -0.81 & -1.42 \\
& Pre-RSQ & 30 & -0.56 & 1.17 \\
& Post-RSQ & 30 & -0.87 & 1.49 \\
\hline
\end{tabular}

\section{Pre-test and Post-test of Resilience Scale Questionnaire}

The paired samples $t$-test was applied to answer the research question comparing the pretest and posttest resilience questionnaire measures in the experimental and control groups. A paired-samples t-test is used since data collection was performed from the experimental and control groups on two different occasions (pretest and posttest of the study). Table 3. represents the results of descriptive statistics for the resilience questionnaire scores in the Experimental and Control groups of 60 junior undergraduates of EFL learners.

\section{Table 3}

Descriptive Statistics for Pretest and Posttest of Resilience Questionnaire Scale

\begin{tabular}{cccccc}
\hline \multicolumn{2}{c}{ Test } & $\boldsymbol{N}$ & Mean & SD & Std. Error Mean \\
\hline \multirow{2}{*}{ Pretest } & Exp. & 30 & 31.82 & 4.418 & .835 \\
& Ctrl. & 30 & 31.93 & 5.043 & 1.052 \\
\multirow{2}{*}{ posttest } & Exp. & 30 & 37.23 & 4.237 & .801 \\
& Ctrl. & 30 & 32.71 & 5.368 & 1.119 \\
\hline
\end{tabular}

Table 3 shows that there are 30 participants in the experimental group and 30 participants in the control group. The mean score of the experimental group in the pretest is 31.82, while it is 37.23 in the posttest which means that they have made improvement. The mean score of the control group in the pretest is 31.93, while in the posttest it is 32.71 , which also means that they also made improvement but as the values indicate, the improvement in the experimental group is more than that in the control group. 
To investigate whether the post test scores of the two groups differed from each other significantly or not, an independent samples t-test was run to see whether the apparent difference between the two groups is statistically significant or not. Table 5 shows the result of the independent samples t-test.

\section{Table 4}

Independent Samples T-test on Exp. And Ctrl Groups' Pretest and Posttest

\begin{tabular}{|c|c|c|c|c|c|c|c|c|c|}
\hline & & \multicolumn{4}{|c|}{ t-test for Equality of Means } & \multirow{3}{*}{$t$} & \multirow{3}{*}{$d f$} & \multirow{3}{*}{ Sig. } & \multirow{3}{*}{$\begin{array}{c}\text { Sig. } \\
\text { (2-tailed) }\end{array}$} \\
\hline & & \multirow{2}{*}{$\begin{array}{c}\text { Mean } \\
\text { Difference }\end{array}$} & \multirow{2}{*}{$\begin{array}{l}\text { Std. Error } \\
\text { Mean }\end{array}$} & \multicolumn{2}{|c|}{$\begin{array}{l}\text { 95\% Confidence Interval } \\
\text { of the Difference }\end{array}$} & & & & \\
\hline & & & & Lower & Upper & & & & \\
\hline \multirow{2}{*}{ 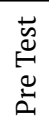 } & EqualValue assumed & -.348 & 1.332 & -3.018 & 2.307 & -.271 & 29 & .473 & .810 \\
\hline & $\begin{array}{l}\text { EqualValue not } \\
\text { assumed }\end{array}$ & -.348 & 1.341 & -3.061 & 2.350 & -.269 & & & .812 \\
\hline \multirow{2}{*}{ 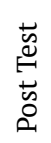 } & EqualValue assumed & 2.863 & 1.353 & .084 & 5.494 & -2.071 & 29 & .238 & .047 \\
\hline & $\begin{array}{l}\text { EqualValue not } \\
\text { assumed }\end{array}$ & 2.863 & 1.372 & .007 & 5.572 & -2.039 & & & .049 \\
\hline
\end{tabular}

The significance values for both pretest and posttest are 0.473 and 0.238 respectively, which are both higher than 0.05; therefore, the researchers consider the first line in Table above which refers to equal variances assumed. So, it can be concluded that the groups were similar at the beginning of the research and there was not a significant difference between them in their pretests, because the sig (2-tailed) value is larger than 0.05 in pretest scores $(0.81>0.05)$ and the magnitude of the mean difference is small $(0.348)$. However, there was a significant difference between the control and the experimental groups on their posttest score (sig. $0.047<0.5$ and the mean difference is 2.86.). Thus, the null hypothesis of 'shielded online education in Covid era does not have any effects on junior Iranian EFL learner undergraduates' resilience level' was rejected. Thus, it can be concluded that shielded online education in Covid era had statistically significant effect on the EFL undergraduate learners' resilience level, and learners in the experimental group outperformed the participants in the control group and since the homogeneity of both groups was determined and shown, the statistical difference between the two groups concerning the enhancement of resiliency level can be attributed to the effect of the shielded online education in Covid era.

\section{Discussion}

The notion of distance learning and online education by implementing the computer software and applications has always been the focus of attention by scholars and specialists in the field of Education and such notions were looked upon as the alternative choices to regular and routine classes. The emergence of Covid-19 virus and the dispersion of such highly infectious virus urged the education stakeholders and policy makers to spotlight online education as the last and best resort and the proper remedy to be established and made dominant in educational realm in the Covid era. Scholars such as Beaunoyer, Dupéré, and Guitton (2020) opined that the digital and online learning agenda and the adaptation problems and deficiencies existed before the Covid era, but the Covid pandemic has exacerbated and spotlighted it. The feasibility of online education in Covid era has not yet been touched upon thoroughly because the educational and academic world is still suffering the adverse effects of Covid pandemic. Human resources along with the internet infrastructure might deem the two prominent agendas in this regard. Teachers' and learners' behavioral pattern have changed dramatically and unnoticeably (Chakraborty, et. al. 2020).

In routine conventional ordinary face-to-face education, teachers would do their best to engage learners in the process of the learning which is taking place. Engagements of the learners inside and outside the classroom would be regarded as signs of academic success (Harper \& Quaye, 2009). The notion of engagement in its three important dimensions as behavioral, emotional, and cognitive engagement (Fredricks, Blumenfeld, \& Paris, 2004) rendered a big deficiency in online education in Covid era. The reason behind such absence could be rooted in the lack of the proper channel of interaction mutually and respectfully (Willms, Friesen, \& Milton, 
2009; Liguori and Winkler, 2020) between teachers and learners in online classes and courses. In most cases such deficiency might result in frustration and de-motivation (Dzakoiria, 2004) on the learners' side which in turn would lead to greater undeniable social losses in the society.

The online education has a lot in common with flipped classrooms to some extents in such a way that in both approaches, the learners take full charge of their own progress, and the notion of autonomy is brought into public attention once more (Khosravani, Khoshsima, \& Mohamadian, 2020; Abdi, 2020). The vantage point is that in Covid online education, the learners are pushed and guided indirectly to become autonomous unintentionally. The dominancy of the online educational programs (Tsai, 2019) for the sake of compensating for the dynamicity of education has shifted the attention gently from the process of education towards the product of better achievements and uptakes in Covid pandemic era in which turn has urged learners more autonomous. Whatever the cause could be, the results and outcomes are welcomed by the education stakeholders and policy makers. Scalars such as AliSalimi and Karimabadi (2021) believe that technologyintegrated or tech-driven learning model (Carroll and Conboy, 2020) with the emphasis on enhancing the capacity of learner engagement should be greatly considered and focused by syllabus designers and materials developers in the new approach to learning in the third millennium.

The shielded online education might have provided the proper ground for learners on the other side of the internet and smart devices with the stress-free learning occasions to accept and enjoy the freedom of loosing threatening characteristics of the instructors and teachers, notions such as the eye contact, the active pursuing questions by the teachers, follow-up questions, frustrations by the nature of the materials for instance mathematics or algebra, and a lot more in order to make use of, or in some rare cases, abuse of the learning environment bestowed by the Covid pandemic and establish a sense of self-achievements and academic success in adverse pandemic situation. This is exactly the definition of resilience provided by Stoltz (1997) but in new Covid version as a revisited definition. The online education in Covid pandemic has exerted a scenario for the learners, a scenario with rearranged values and interconnectedness which at first sight deems big challenges and adversities. Empirical studies conducted in Bangladesh (Khan et al., 2020), China (Jiang, 2020), France (Essadek \& Rabeyron, 2020), Greece (Kaparounaki et al., 2020), UK (Savage et al., 2020), and USA (Copeland et al., 2021) highlighted a common notion of mental disorders of varying severity experienced by large proportion of students during Covid-19 pandemic online education. The learners get involved in the imposed learning situation. Little by little and turn the imposed inadvertent engagements and challenges into brand new learning opportunities in his/her educational progress. Such courses of actions could best depict new trend of thoughts in defining resiliency notion in educational realm.

\section{Conclusion}

The present study aimed at investigating the challenges embracing online education in the Covid pandemic and the reflections teachers and learners display on the pivot of learning and learners' role in accomplishing the educational targets. The other side of the coin in the present paper was the notion of resiliency issues. Covid pandemic as the global adversity affected the educational realm is the focus of academic debates as the behaviors to such great adversity is out of control of the policy makers just because individuals might perform diversely in different occasions. Resilience is the capacity to change and to welcome change as there is always resistance to change generally. Through resiliency, all challenges turn into opportunities if individuals accept and view adversities and challenges from positive vantage points. Even bearing such vantage points is also required to read between the lines of the present study. The Covid pandemic and the challenges imposed to all areas of activities especially educational and academic realm are still vague and untouched. What is clear is that online education in a shielded fashion was the last and best resort in the status quo. Each and every point pinpointed here could be view in two layers of fighting the issues or making use of the opportunities the adversities provide. Any negative or contrary-to-the-norm occurrences could bear positive opportunities inside.

The opportunities provided through shielded online education widen new horizons and new platforms for researchers and stakeholders. Of course, the focus of the present paper was on the educational challenges encountered in Covid era through online education and the knowhow to turn them into learning opportunities. Such documentations which are rooted in experiences should not be left alone, and after the Covid nightmare is over, academic and educational centers along with policy makers and stake holders should propose a mixed 


\section{AN APPRAISAL LOOK INTO SHIELDED ONLINE EDUCATION IN COVID ERA}

method approach in a blended fashion within regular routine educational environments and settings in order to maximize the uptakes of different learners with different tastes. The researchers in the present study do believe that reality is far from ideality, hence they aimed at depicting the hidden irritating and debilitating challenges underlying shielded online education in Covid pandemic and in the long run, spotlight the sunny side of the challenges so that the resiliency of the successful participants in Covid era could be brought into attention and in turn the findings and the trend of thoughts could shed light on the frameworks and blueprints of education by stakeholders, policy makers, syllabus designers, materials developers, academicians, specialists and learners involved directly or indirectly in education fields.

\section{Concluding Remark}

The findings and spotlighted issues in the present research could be valuable for policy makers, stakeholders, specialists in education and anyone involved in the field of education. Of course, the Covid era is not over yet and there is a long way ahead as the side effects may pop up inadvertently in the axis of time and space anytime anywhere. The final concluding remark bears that the population studied in the present study were all junior undergraduates; hence, each semester, young novice learners commence their study at universities in different discipline. The researchers do believe that if the subjects of the present study were new beginners and freshmen at university who had the slightest idea on the academic settings and atmosphere in higher education, the results could be challenging in nature, and it is sensed that the need to delve into the challenges of freshmen students in Covid era is demanding and needs thorough investigation.

The researchers of the present study do hope that the other aspects of the shielded online education in Covid era, the notions such as learners with special educational needs having learning difficulties, such as hearing or visual impairment and mobility disabilities roughly touched in the present study could be examined and introduced to the ongoing trend of online education in order to empower and reinforce the educational body in action and in turn meet the needs of the practitioners in due time.

\section{Declaration of Competing Interest}

None declared.

\section{References}

Abdi, M. (2020). Coronavirus disease 2019 (Covid-19) outbreak in Iran: Actions and problems. Infect Control Hosp Epidemiol, 41(6), 754-755. https://doi.org/10.1017/ice.2020.86.

Adedoyin, O.B., \& Soykan, E. (2020). Covid-19 pandemic and online learning: The challenges and opportunities. Interactive Learning Environments. https://doi.org/10.1080/10494820.2020.1813180

AliSalimi, E., \& Karimabadi, M. (2021). The efficacy of classroom flipping on Iranian intermediate EFL learners' engagement and their perception of the flipped classroom model. Journal of Teaching Language Skills, 39(3), 143-180. https://doi.org/10.22099/jtls.2021.38824.2901

Arora, A., Chakraborty, P., Bhatia, M. P. S., \& Mittal, P. (2020). Role of emotion in addictive use of twitter during Covid-19 imposed lock-down in India. Journal of Technology in Behavioral Science. https://doi.org/10.1007/ s41347-020-00174-3

Bachman, L. F. (2005). Statistical analysis for language assessment (2nd ed.). Cambridge University Press.

Bao, W. (2020). Covid-19 and online teaching in higher education: A case study of Peking University. Human Behavior and Emerging Technologies, 2(2), 113-115. https://doi.org/10.1002/hbe2.191

Beaunoyer, E., Dupéré, S., \& Guitton, M. J. (2020). Covid-19 and digital inequalities: Reciprocal impacts and mitigation strategies. Computers in Human Behavior, 111, 106424. https://dx.doi.org/10.1016\%2Fj. chb.2020.106424

Bozkurt, A., \& Sharma, R. C. (2020). Emergency remote teaching in a time of global crisis due to corona virus pandemic. Asian Journal of Distance Education, 15(1), i-iv. http://dx.doi.org/10.5281/zenodo. 3778083

Carroll, N., \& Conboy, K. (2020). Normalising the "new normal": Changing tech-driven work practices under pandemic time pressure. International Journal of Information Management, 55, 102186. https://doi. org/10.1016/j.ijinfomgt.2020.102186

Chakraborty, P., Mittal, P., Gupta, M.S., Yadav, S., \& Arora, A. (2020). Opinion of students on online education 
during the Covid-19 pandemic. Human Behavior \& Emerging Technologies, 3(3), 357-365. https://doi. org/10.1002/hbe2.240

Chen, G., \& Martin, R. A. (2007). A comparison of humor styles, coping humor, and mental health between Chinese and Canadian university students. Humor: International Journal of Humor Research, 20, 215-234. https://doi.org/10.1515/HUMOR.2007.011

Copeland, W. E., McGinnis, E., Bai, Y., Adams, Z., Nardone, H., Devadanam, V., Rettew, J., \& Hudziak, J.J. (2021). Impact of Covid on college student mental health and wellness. Journal of the American Academy of Child \& Adolescent Psychiatry, 60 (1), 134-141. https://doi.org/10.1016/j.jaac.2020.08.466

David, J. (2011). Computing by distance education: Problems and solutions. In Integrating technology into computer science education (pp 139-146). Association for Computing Machinery.

Dhawan, S. (2020). Online learning: A panacea in the time of Covid-19 crises. Journal of Educational Technology, 49(1), 5-22. https://doi.org/10.1177/0047239520934018

Dzakoiria, H. (2004). Technology does not always teach distance learners, but effective distance teachers do. Malaysian Online Journal of Instructional Technology, 1(1), 60-81.

Essadek, A., \& Rabeyron, T. (2020). Mental health of French students during the Covid-19 pandemic. Journal of Affective Disorders, 277, 392-393. https://dx.doi.org/10.1016\%2Fj.jad.2020.08.042

Fardin, M.A. (2020). Covid-19 and anxiety: A review of psychological impacts of infectious disease outbreaks. Archives of Clinical Infectious Diseases, 15(Covid-19), e102779. https://doi.org/10.5812/archcid.102779

Fredricks, J. A., Blumenfeld, P. C., \& Paris, A. (2004). School engagement:Potential of the concept: State of the evidence. Review of Educational Research, 74(1), 59-119. https://doi.org/10.3102/0034654 3074001059.

Grishchenko, N. (2020). The gap not only closes: Resistance and reverse shifts in the digital divide in Russia. Telecommunications Policy, 44(8), 102004. https://doi.org/10.1016/j.telpol.2020.102004

Harper, S. R., \& Quaye, S. J. (2009). Student engagement in higher education: Theoretical perspectives and practical approaches for diverse populations. Routledge.

Hasan, N., \& Bao, Y. (2020). Impact of "e-learning crack-up" perception on psychological distress among college students during Covid-19 pandemic: A mediating role of "fear of academic year loss". Children and Youth Services Review, 118, 105355. https://dx.doi.org/10.1016\%2Fj.childyouth.2020.105355

Hauck, M., \& Haezewindt, B. (1999). Adding a new perspective to distance (language) learning and teaching The tutor's perspective. ReCALL, 11(2), 46-54. https://doi.org/10.1017/S095834400000495X

Heidari-Shahreza, M. A. (2020). Humor-intergrated language learning (HILL): Teaching with and about humor. In J. Rucynski, \& C. Prichard (Eds.), Bridging the humor barrier: Humor competence training in English language teaching (pp. 79-106). Lexington Books, Rowman \& Littlefield Publishers.

Holec, H. (1981). Autonomy and foreign language learning. Pergamon

Hutton, J. L. (1998). The learning styles of first year education students. The Open Polytechnic of New Zealand.

Islam, M., Lamb, M., \& Chambers, G. (2013). The L2 motivational self system and national interest: A Pakistani perspective. System, 41, 231-244. https://ssrn.com/abstract $=3693795$

Islam, M.A., Barna, S.D., Raihan, H., Khan, M.N.A., \& Hossain, M.T. (2020). Depression and anxiety among university students during the Covid-19 pandemic in Bangladesh: A web-based cross-sectional survey. PLoS One, 15(8), e0238162. https://doi.org/10.1371/journal.pone.0238162

Jiang, R. (2020). Knowledge, attitudes and mental health of university students during the Covid-19 pandemic in China. Children and Youth Services Review, 119, 105494. https://doi.org/10.1016/j.childyouth.2020.105494

Kaparounaki, C. K., Patsali, M. E., Mousa, D. P. V., Papadopoulou, E. V., Papadopoulou, K. K., \& Fountoulakis, K. N. (2020). University students' mental health amidst the Covid-19 quarantine in Greece. Psychiatry Research, 290, 113111. https://dx.doi.org/10.1016\%2Fj.psychres.2020.113111

Kember, D. (2003). To control or not to control: The question of whether experimental designs are appropriate for evaluating teaching innovations in higher education. Assessment \& Evaluation in Higher Education, 28(1), 89-101. https://psycnet.apa.org/doi/10.1080/02602930301684

Khan, A. H., Sultana, M. S., Hossain, S., Hasan, M. T., Ahmed, H. U., \& Sikder, M. T. (2020). The impact of Covid-19 pandemic on mental health \& wellbeing among home-quarantined Bangladeshi students: A cross-sectional pilot study. Journal of Affective Disorders, 277, 121-128. https://doi.org/10.31234/osf.io/97s5r

Khosravani, M., Khoshsima, H., \& Mohamadian, A. (2020). On the effect of flipped classroom on learners' achievement, autonomy, motivation and WTC: Investigating learning and learner variables.Journal of English Language Teaching and Learning, 12(25), 175-189.

Kinzie, J. (2010). Student engagement and learning: Experiences that matter. In J. Christensen Hughes, \& J. Mighty (Eds.), Taking stock: Research on teaching and learning in higher education (pp. 139-153). McGillQueen's University Press.

Kline, P. (2000). The handbook of psychological testing. Routledge.

Lee, M. J. W., \& Chan, A. (2007). Reducing the effects of isolation and promoting inclusivity for distance learners 


\section{AN APPRAISAL LOOK INTO SHIELDED ONLINE EDUCATION IN COVID ERA}

through podcasting. Turkish Online Journal of Distance Education, 8(1), 85-105.

Lembani, R., Gunter, A., Breines, M., \& Dalu, M.T.B. (2020). The same course, different access: The digital divide between urban and rural distance education students in South Africa. Journal of Geography in Higher Education, 44(1), 70-84. https://doi.org/10.1080/03098265.2019.1694876

Liguori, E., \& Winkler, C. (2020). From offline to online: Challenges and opportunities for entrepreneurship education following the Covid-19 pandemic. Entrepreneurship Educational Pedagogy, 3(4), 346-51. https://doi. org/10.1177/2515127420916738.

Liu, M., \& Huang, W. (2011). An exploration of language anxiety and English learning motivation. Education Research International, 2011, 1-8. https://doi.org/10.1155/2011/493167

Maggio, L. A., Daley, B. J., Pratt, D. D., Torre, D. M. (2018). Honoring thyself in the transition to online teaching. Academic Medicine, 93(8), 1129-1134. https://doi.org/10.1097/ACM.

Mahmood, S. (2020). Instructional strategies for online teaching in Covid-19 pandemic. Human Behavior and Emerging Technologies, 3, 199-203. https://doi.org/10.1002/hbe2.218

Mireault, G. C., \& Reddy, V. (2016). Humor in infants: Developmental and psychological perspectives. Springer.

Mitchell, C. (2017). Language education pressures in Japanese high schools. Japan Association for Language Teaching Shiken, 21(1), 1-11.

Morgan, C., \& O’Reilly, M. (1999). Assessing open and distance learners. Stylus Pub. Inc.

Omotayo, F.O., \& Haliru, A. (2020). Perception of task-technology fit of digital library among undergraduates in selected universities in Nigeria. The Journal of Academic Librarianship, 46(1), 102097. https://doi.org/10.1016/j. acalib.2019. 102097

Papi, M. (2010). The L2 motivational self-system, L2 anxiety, and motivated behavior: A structural equation modeling approach. System, 38(1), 467-479. https://doi.org/10.1016/j.system.2010.06.011

Patricia, A. (2020). College students' use and acceptance of emergency online learning due to Covid-19. International Journal of Educational Research Open, 1, 100011. https://doi.org/10.1016/j.ijedro.2020.100011

Peirce, B. (1996). Interpreting data: The role of theory. TESOL Quarterly, 30, 337-340.

Peters, O. (1992). Some observations on dropping out in distance education. Distance Education, 13(2), 234- 269. https://doi.org/10.1080/0158791920130206

Pokhrel, S., \& Chhetri, R. (2021). A literature review on impact of Covid-19 Pandemic on teaching and learning. Higher Education for the Future, 8(1), 133-141. https://doi.org/10.1177/2347631120983481

Reeves, T. C. (2000). Alternative assessment approaches for online learning environments in higher education. Educational Computing Research, 23(1), 101-111. https://doi.org/10.2190\%2FGYMQ-78FA-WMTX-J06C

Rumble, G. (1995). Labor market theories and distance education I: Industrialization and distance education. Open Learning, 10(1), 11-20. https://doi.org/10.1080/0268051950100203

Savage, M.J., James, R., Magistro, D., Donaldson, J., Healy, L.C., Nevill, M., \& Hennis, P.J. (2020). Mental health and movement behavior during the Covid-19 pandemic in UK university students: Prospective cohort study. Mental Health and Physical Activity, 19, 100357. https://doi.org/10.1016/j.mhpa.2020.100357

Stoltz, P.G. (2000).Adversity quotient at work; make everyday challenges the key to your success - Putting the principles of $A Q$ into action. Morrow

Stoltz, P. G. (1997). Adversity quotient, turning obstacles into opportunities. Wiley.

Tsai, Y. R. (2019). Promotion of learner autonomy within the framework of a flipped EFL instructional model: Perception and perspectives.Computer Assisted Language Learning, 1(1), 1-32. https://doi.org/10.1080/09588 221.2019.1650779

Tullis, K. J., \& Camey, J. P. (2007). Strategic implications of specialized business school accreditation: End of the line for some business education programs? Journal of Education for Business, 83(1), 45-51. https://doi. org/10.3200/JOEB.83.1.45-51

Wagnild, G. M. (2013). Development and use of the Resilience Scale (RS) with middle-aged and older adults. In S. Prince-Embury, \& D. H. Saklofske (Eds.), Resilience in children adolescents and adults (pp. 151-160). Springer.

Wagnild, G. M., \& Young, H. M. (1993). Development and psychometric evaluation of the Resilience Scale. Journal of Nursing Measuring, 1(2), 165-178.

Wang, N., Chen, J., \& Zhang, J. (2021). Developing and integrating constructive CALL courseware for EAP in Chinese universities: A report on a case study. Computer Assisted Language Learning. https://doi.org/10.108 $0 / 09588221.2021 .1895226$

Wang, Z, Bergin, C., \& Bergin, D. A. (2014). Measuring engagement in fourth to twelfth-grade classrooms: The classroom engagement inventory. School Psychology Quarterly, 29(4), 517-535. https://doi.org/10.1037/ spq0000050

Willms, J. D., Friesen, S. \& Milton, P. (2009). What did you do in school today? Transforming classrooms through social, academic and intellectual engagement. Canadian Education Association. 
Appendix A

\section{Oxford Placement Test}
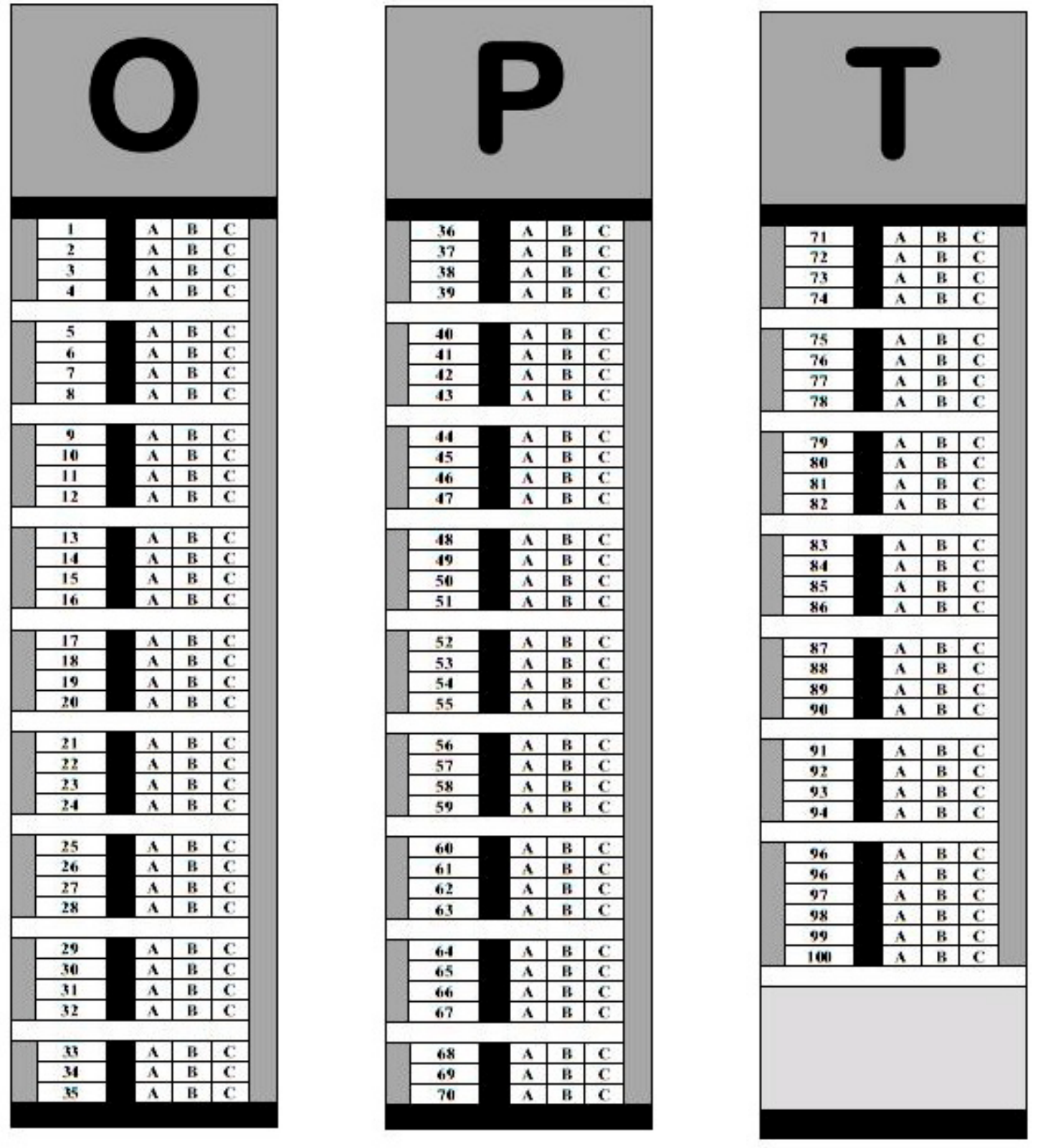


\section{Appendix B}

\begin{tabular}{|c|c|c|c|c|c|c|c|}
\hline \multicolumn{8}{|c|}{$\begin{array}{l}\text { Please read the following statements. To the right of each you will find seven numbers, ranging from } \\
\text { "1" (Strongly Disagree) on the left to "7" (Strongly Agree) on the right. Click the circle below the } \\
\text { number which best indicates your feelings about that statement. For example, if you strongly } \\
\text { disagree with a statement, click "1". If you are neutral, click " } 4 \text { ", and if you strongly agree, click "7", } \\
\text { etc. }\end{array}$} \\
\hline & & $\begin{array}{l}\text { ingly } \\
\text { gree }\end{array}$ & & & & & $\begin{array}{l}\text { Ongly } \\
\text { Agree }\end{array}$ \\
\hline 1. When I make plans, I follow through with them. & $\begin{array}{r}1 \\
\mathbb{C}\end{array}$ & $\begin{array}{l}2 \\
\mathrm{C}\end{array}$ & $\begin{array}{r}3 \\
\mathrm{C}^{3}\end{array}$ & $\begin{array}{r}4 \\
{[}\end{array}$ & $\begin{array}{r}5 \\
E\end{array}$ & $\begin{array}{r}6 \\
\mathrm{C}\end{array}$ & $\begin{array}{r}7 \\
\mathrm{C}\end{array}$ \\
\hline 2. I usually manage one way or another. & $\begin{array}{r}1 \\
\mathbf{C}\end{array}$ & ${ }^{2}$ & $\mathrm{C}^{3}$ & $\begin{array}{r}4 \\
\mathrm{C}\end{array}$ & $\begin{array}{r}5 \\
\mathrm{C}\end{array}$ & $\begin{array}{r}6 \\
\mathrm{C}\end{array}$ & $\begin{array}{r}7 \\
C^{7}\end{array}$ \\
\hline 3. I am able to depend on myself more than anyone else. & $\begin{array}{r}1 \\
\mathrm{C} \\
\end{array}$ & L & $\mathrm{C}^{3}$ & $\begin{array}{r}4 \\
\mathbf{C}\end{array}$ & $\begin{array}{r}5 \\
\mathrm{C}\end{array}$ & $\begin{array}{r}6 \\
\mathrm{C}\end{array}$ & $\begin{array}{r}7 \\
\mathbf{C}\end{array}$ \\
\hline 4. Keeping interested in things is important to me. & $\begin{array}{r}1 \\
\mathbf{C}\end{array}$ & 2 & $\begin{array}{r}3 \\
\mathrm{C}^{3}\end{array}$ & $\begin{array}{r}4 \\
\mathbf{C}\end{array}$ & $\begin{array}{r}5 \\
\mathrm{C}\end{array}$ & C & $\begin{array}{r}7 \\
C^{7}\end{array}$ \\
\hline 5. I can be on my own if I have to. & $\begin{array}{r}1 \\
\mathbb{C}\end{array}$ & 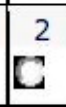 & $\mathbb{C}^{3}$ & $\begin{array}{r}4 \\
\mathrm{C}\end{array}$ & 5 & $\begin{array}{r}6 \\
\mathrm{C}\end{array}$ & $\begin{array}{r}7 \\
\mathrm{C}\end{array}$ \\
\hline 6. I feel proud that I have accomplished things in life. & $\begin{array}{l}1 \\
\mathrm{C} \\
\end{array}$ & $\begin{array}{r}2 \\
{[} \\
\end{array}$ & $\mathrm{C}^{3}$ & $\begin{array}{r}4 \\
{[} \\
\end{array}$ & $\begin{array}{r}5 \\
\mathbb{C}^{-}\end{array}$ & $\begin{array}{r}6 \\
\mathrm{C}\end{array}$ & $\begin{array}{r}7 \\
C^{7}\end{array}$ \\
\hline 7. I usually take things in stride. & $\begin{array}{l}1 \\
\mathrm{C} \\
\end{array}$ & $\begin{array}{r}2 \\
\mathbf{C}\end{array}$ & $\begin{array}{r}3 \\
{[}\end{array}$ & $\begin{array}{r}4 \\
{[} \\
\end{array}$ & $\begin{array}{r}5 \\
\mathrm{C} \\
\end{array}$ & $\begin{array}{r}6 \\
\mathrm{C}\end{array}$ & $\begin{array}{r}7 \\
\mathbf{C}\end{array}$ \\
\hline 8. I am friends with myself. & $\begin{array}{l}1 \\
\mathrm{C} \\
\end{array}$ & $\begin{array}{l}2 \\
\mathrm{C}\end{array}$ & $\mathrm{C}^{3}$ & $\begin{array}{r}4 \\
{[} \\
\end{array}$ & $\begin{array}{r}5 \\
\mathrm{C} \\
\end{array}$ & $\begin{array}{l}6 \\
\mathrm{C} \\
\end{array}$ & $\begin{array}{r}7 \\
\mathrm{C} \\
\end{array}$ \\
\hline 9. I feel that I can handle many things at a time. & $\begin{array}{r}1 \\
\mathbf{C} \\
\end{array}$ & $\begin{array}{l}2 \\
\mathrm{C}\end{array}$ & $\mathrm{C}^{3}$ & $\begin{array}{r}4 \\
{[} \\
\end{array}$ & $\begin{array}{r}5 \\
\mathrm{C} \\
\end{array}$ & $\begin{array}{r}6 \\
\mathrm{C} \\
\end{array}$ & $\begin{array}{r}7 \\
\mathrm{C} \\
\end{array}$ \\
\hline 10. I am determined. & $\begin{array}{r}1 \\
\mathbf{C}\end{array}$ & $\begin{array}{l}2 \\
\mathrm{C}\end{array}$ & $\mathrm{C}^{3}$ & $\begin{array}{r}4 \\
\mathrm{C}\end{array}$ & $\begin{array}{r}5 \\
\mathbb{C}\end{array}$ & $\begin{array}{r}6 \\
\mathbf{C}\end{array}$ & $\begin{array}{r}7 \\
\mathbf{C}\end{array}$ \\
\hline 11. I seldom wonder what the point of it all is. & $\begin{array}{r}1 \\
\mathrm{C} \\
\end{array}$ & $\begin{array}{l}2 \\
\mathrm{C}\end{array}$ & $\begin{array}{r}3 \\
\mathrm{C}^{3}\end{array}$ & $\begin{array}{r}4 \\
{[} \\
\end{array}$ & $\begin{array}{r}5 \\
\mathrm{C} \\
\end{array}$ & $\begin{array}{r}6 \\
\mathrm{C}\end{array}$ & $\begin{array}{r}7 \\
\\
\end{array}$ \\
\hline 12. I take things one day at a time. & $\begin{array}{l}1 \\
\mathbf{C} \\
\end{array}$ & $\begin{array}{l}2 \\
\mathrm{C}\end{array}$ & $\begin{array}{r}3 \\
\mathrm{C}^{2}\end{array}$ & $\begin{array}{r}4 \\
\mathrm{C}\end{array}$ & $\begin{array}{r}5 \\
\mathrm{C}\end{array}$ & $\begin{array}{r}6 \\
\mathrm{C}\end{array}$ & $\begin{array}{r}7 \\
\mathrm{C}\end{array}$ \\
\hline $\begin{array}{l}\text { 13. I can get through difficult times because I've experienced } \\
\text { difficulty before. }\end{array}$ & $\mathbf{C}$ & 2 & C & 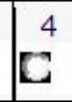 & 5 & 6 & C \\
\hline 14. I have self-discipline. & $\mathbf{C}$ & 2 & $\mathbf{C}$ & C & 5 & 6 & $\mathbf{C}$ \\
\hline 15. I keep interested in things. & 1 & 2 & 3 & 4 & 5 & 6 & 7 \\
\hline
\end{tabular}

